\title{
The Role of Gender in Individual and Group Decision Making: A Research Model
}

\author{
Qi Deng, Shaobo Ji \\ Sprott School of Business, Carleton University, Ottawa, Canada \\ Email: qideng3@cmail.carleton.ca, shaobo.ji@carleton.ca
}

Received December 2013

\begin{abstract}
Confronting with numerous investment choices, investors, either individual or group, invariably need to make the decision under some level of risk. Therefore, it is important to assess the risk attitudes and to examine the diversity of risk attitudes among different decision makers. In this paper, we focus on the risk preferences of male and female at both the individual and the group levels. We propose a conceptual model to examine three questions: 1) Does gender difference have an impact on individual decision making under risk? 2) Does decision context (individual decision vs. group decision) influence the decision making under risk? 3) Does the gender composition affect the risk preference of group decision making? Accordingly, a number of research hypotheses are proposed and are recommended to be tested using lottery-choice experiments.
\end{abstract}

\section{Keywords}

\section{Individual and Group Decision Making; Gender Difference; Risk Preference}

\section{Introduction}

There are three types of problem: simple, complicated and complex problems [1]. Investment decision making, which invariably involves some uncertainty, is a complex problem. There are numerous variables, both known and unknown, to consider in investment decision. Often, the decision is a result of a strenuous effort exercised between one's expectations and preferences. Individual differences, in the form of demographics, psychological traits, and even physiology, and their impacts on decision makings have long been recognized and researched [2]. Among many, gender difference has gained a lot of attentions because of the increasingly participation of women in business and investment decisions. In addition, decision making in group context has also been paid attention among researchers due to greater emphasis of collective, group oriented work environment. This paper aims to examine the role of gender and group gender composition in decision making. A research model and a number of research hypotheses are derived based on reviews of previous studies.

\section{Individual and Group Decision Making}

At individual level, decision making, especially under uncertainty, is a complex mental process given that both cognitive and emotional factors are involved [3]. It has been argued that individual decision making under risk 
can be seen as the outcome of the confrontation between expectations and preference [4]. Many models have been constructed to describe the decision making [5-7]. In addition, many demographic factors have been examined in previous studies, e.g., gender [8,9], age [10], past experience [11], social context [12] and learning [13]. For instance, in [8], two experiments were conducted to investigate gender differences in risk taking behavior, using a computerized military game. It was found that females showed lower risk preference than males when subjects repeated a previously undertaken task. Reported in [14], it was found that female entrepreneurs are less willing than male entrepreneurs to become involved in situations with uncertain outcomes. By dividing the decision makers into two groups, a "non-managerial" group in which the majority of individuals have not undergone formal management education and a "managerial" population of potential and actual managers who have undertaken such education, and examining the betting behaviors in these two groups, Johnson and Powell [9] found a lower preference for risk amongst women in the "non-managerial" group. Similarly, Levin, Snyder, \& Chapman [15] reported a lower risk preference amongst women in their experiment on gambling. Furthermore, strong evidences that females are less inclined to take risks than males have been found in both the general and business literatures [16-20].

Compared with individual level, it is found that decision by group is different from decision by individual, especially when decision is under risk [21]. Many studies have been conducted to explain this phenomenon and explanations have been offered. For instance, it is possible that individual choice preferences change when people act in groups because of the responsibility diffusion [22], cultural values of group [23], and individual familiarity with the decision problem [24]. Members who are greater risk takers may exert stronger influence within the group more than others [25]. In addition, some studies have suggested that groups are more risk-averse in lotteries with low probabilities of winning the largest payoffs, but less risk-averse when these probabilities are high [26-28]. Moreover, groups are found to have a smaller variance in their risk preferences than individuals. Interest in group decision making has been extended to include size and gender composition, e.g., couples [29,30], female only groups [26], and mixed-gender teams [16]. In general, it was found that groups are more rational and risk neutral agents than single individuals [31].

\section{Research Model and Research Hypotheses}

In this paper, the role of gender in individual and group decision making under risk is examined. On the basis of the literature review, a research model is proposed, as shown in Figure 1. In this model, individual and group represent different decision contexts. Individual represents a decision context in which decisions are made by single decision maker and the decision maker take full responsibility for outcomes. Group stands for a decision context in which decisions are made by group members and every group can only make one unanimous decision for every question. Outcomes, as well as responsibilities, of decisions made by group will be equally shared by every group member. It is argued that risk preference is affected by gender, group, as well as group gender composition. For individual decision making, risk preferences will be examined by gender. For group decision making context, three-member groups will be formed with various gender composition combinations. For example, shown in Figure 1 under the label of Group, A $(3,0)$ represents a group with 3-male and 0-female members; B (2, 1) represents a group with 2-male and 1-female members; C $(1,2)$ represents a group with 1male and 2-female members; and $\mathrm{D}(0,3)$ represents a group with 0 -male and 3 -female members. It is speculated and assumed that an individual's risk preference is an indicator of attitude toward risk. The proposed model is based on an underlying hypothesis that no obstacles exist between risk preference and risk decision making so that risk preference could be indicated by the count of risk decisions made by decision makers. The relationship between decision context and risk preference can be divided into three levels, which we elaborate by proposing several primary hypotheses as follows.

At the individual level, we speculate that male is more risk seeking that female. Hence, the following hypo-

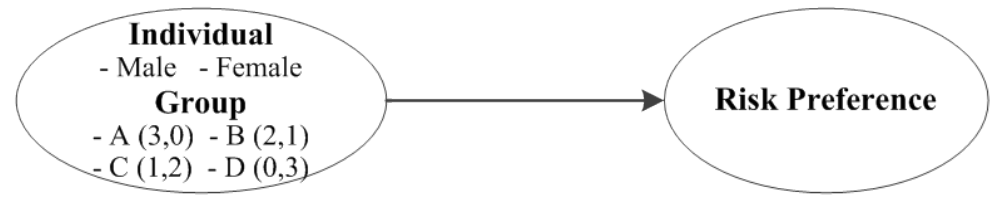

Figure 1. Gender and group in decision making. 
thesis is proposed: Male is more risk-seeking than female (H1). At the group level, to test the role of gender and gender composition in group, a three-member group is proposed and its risk preference is measured as a group. Due to the requirement of unanimity, group risk preference will not be a simple sum of group members' risk preferences. Rather, potential interactions between group members make the group decision making more complicated than individual decision making. Similar to the articulation in Hypothesis 1, the following hypothesis is proposed with regard to gender and gender composition in group context: Group risk preference increases with the percentage of male group members (H2). To assess the difference of risk preference between individual and group, two comparisons will be conducted, i.e., male individual vs. all male group, and female individual vs. all female group. As discussed in Section 2, the following hypotheses are formulated with regard to the comparisons between individual and group's risk preference when gender and gender composition of a group are considered. Group is more risk-averse than individual (H3.1); all male group is more risk-averse than male individual (H3.2); and all female group is more risk-averse than female individual (H3.3).

\section{Research Design}

Because of the difficulty in observing and identifying group decision making under risk with field research or the lack of field data, most studies used laboratory experiments to explore group decision making under risk. The lottery-choice experiments have been used to measure risk preference in many studies $[26,28]$ and could be used to test the hypotheses for the proposed study. In a lottery-choice experiment, a menu of ten lottery-choice decisions is designed to assess the risk preference. Each decision represents a choice between a relatively "safe" lottery and a more "risky" lottery. The probability of the high-payoff outcome increases in $10 \%$ increments from $10 \%$ in the first decision to $100 \%$ in the last decision, while payoffs are identical in all ten lottery-choice decisions. In each decision, the subjects (either individual or group) will be asked to choose which lottery he preferred to play. The total number of safe lottery choices is used as a measurement of a subject's risk reference. Through comparing it with the risk-neutral benchmark of choosing the lottery with the highest expected monetary payoff for all probabilities, one can identify whether a subject is risk averse or risk seeking.

\section{Discussion}

Although the impact of gender on individual decision making has been studied for many years, gender differences at group levels have not been examined extensively. The study proposes to explore the impact of gender on group decision making by introducing the concept of gender composition in group. The proposed study is designed draw inferences on the external validity of earlier studies by keeping the subject pool comparable to some earlier studies with three-person groups. Practically, the findings of the proposed research will provide some evidences for organizations to consider in terms of decision maker's gender, and team composition.

\section{References}

[1] Westley, F., Zimmerman, B. and Patton, M. (2007) Getting to Maybe: How the World Is Changed. Toronto: Vintage Canada.

[2] Coates, J. (2012) The Hour between Dog and Wolf: Risk Taking, Gut Feelings and the Biology of Boom and Bust. Toronto: Random House Canada.

[3] Loewenstein, G.F., Weber, E.U., Hsee, C.K. and Welch, N. (2001) Risk as Feelings. Psychological Bulletin, 127, 267-286. http://dx.doi.org/10.1037/0033-2909.127.2.267

[4] Antonides G. and Van Der Sar, N.L. (1990) Individual Expectations, Risk Perception and Preferences in Relation to Investment Decision Making. Journal of Economic Psychology, 11, 227-245. http://dx.doi.org/10.1016/0167-4870(90)90005-T

[5] Kahneman, D. and Tverksy, A. (1979) Prospect Theory: An Analysis of Decision under Risk. Econometrica, 47, 263-291. http://dx.doi.org/10.2307/1914185

[6] Quiggin J. (1982) A Theory of Anticipated Utility. Journal of Economic Behavior \& Organization, 3, 323-343. http://dx.doi.org/10.1016/0167-2681(82)90008-7

[7] Yaari M.E. (1987) The Dual Theory of Choice under Risk. Econometrica: Journal of the Econometric Society, 55, 95-115. http://dx.doi.org/10.2307/1911158

[8] Hudgens, G.A. and Fatkin, L.T. (1985) Sex Differences in Risk Taking: Repeated Sessions on a Computer-Simulated 
Task. The Journal of Psychology, 119, 197-206. http://dx.doi.org/10.1080/00223980.1985.10542887

[9] Johnson J.E.V. and Powell P.L. (1994) Decision Making, Risk and Gender: Are Managers Different? British Journal of Management, 5, 123-138. http://dx.doi.org/10.1111/j.1467-8551.1994.tb00073.x

[10] Gardner M. and Steinberg L. (2005) Peer Influence on Risk Taking, Risk Preference, and Risky Decision Making in Adolescence and Adulthood: An Experimental Study. Developmental Psychology, 41, 625-635. http://dx.doi.org/10.1037/0012-1649.41.4.625

[11] Cohen, M., Etner, J. and Jeleva, M. (2008) Dynamic Decision Making when Risk Perception Depends on Past Experience. Theory and Decision, 64, 174-192. http://dx.doi.org/10.1007/s11238-007-9061-3

[12] Simon J. and Lee, C. (2010) Uncertain Futures: Individual Risk and Social Context in Decision-Making in Cancer Screening. Health, Risk \& Society, 12, 101-117. http://dx.doi.org/10.1080/13698571003637048

[13] Khwaja A., Sloan F. and Chung S. (2006) Learning About Individual Risk and the Decision to Smoke. International Journal of Industrial Organization, 24, 683-699. http://dx.doi.org/10.1016/j.ijindorg.2005.10.004

[14] Sexton, D.L. and Bowman-Upton, N. (1990) Female and Male Entrepreneurs: Psychological Characteristics and Their Role in Gender-Related Discrimination. Journal of Business Venturing, 5, 29-36. http://dx.doi.org/10.1016/0883-9026(90)90024-N

[15] Levin, I.P., Snyder, M.A. and Chapman, D.P. (1988) The Interaction of Experiential and Situational Factors and Gender in a Simulated Risky Decision-Making Task. The Journal of Psychology, 122, 173-181. http://dx.doi.org/10.1080/00223980.1988.9712703

[16] Karakowsky, L. and Elangovan A. (2001) Risky Decision Making in Mixed-Gender Teams: Whose Risk Tolerance Matters? Small Group Research, 32, 94-111. http://dx.doi.org/10.1177/104649640103200105

[17] Kogan, N. and Dorros, K. (1978) Sex Differences in Risk Taking and Its Attribution. Sex Roles, 4, 755-765. http://dx.doi.org/10.1007/BF00287336

[18] Roberts, G.C. (1975) Sex and Achievement Motivation Effects on Risk Taking. Research Quarterly, 46, 58-70. http://dx.doi.org/10.1080/10671315.1975.10615305

[19] Slovic, P. (1966) Risk Taking in Children: Age and Sex Differences. Child Development, 37, 169-176. http://dx.doi.org/10.2307/1126437

[20] Thomas, G.P. and Garvin, A.D. (1973) Sex Differences in Risk Taking on Essay Tests. Journal of the Student Personnel Association for Teacher Education, 12, 32-36. http://dx.doi.org/10.1002/j.2164-6171.1973.tb00043.x

[21] Madaras, G.R. and Bem, D.J. (1968) Risk and Conservatism in Group Decision-Making. Journal of Experimental Social Psychology, 4, 350-365. http://dx.doi.org/10.1016/0022-1031(68)90062-0

[22] Wallach, M.A., Kogan, N. and Bem, D.J. (1964) Diffusion of Responsibility and Level of Risk Taking in Groups. Journal of Abnormal and Social Psychology, 68, 263-274. http://dx.doi.org/10.1037/h0042190

[23] Stoner, J.A.F. (1968) Risky and Cautious Shifts in Group Decisions: The Influence of Widely Held Values. Journal of Experimental Social Psychology, 4, 442-459. http://dx.doi.org/10.1016/0022-1031(68)90069-3

[24] Bateson, N. (1966) Familiarization, Group Discussion and Risk Taking. Journal of Experimental Social Psychology, 2, 119-129. http://dx.doi.org/10.1016/0022-1031(66)90073-4

[25] Van Knippenberga, D., Van Knippenberg B. and Van Dijk E. (2000) Who Takes the Lead in Risky Decision Making? Effects of Group Members' Risk Preferences and Prototypicality. Organizational Behavior and Human Decision Processes, 83, 213-234. http://dx.doi.org/10.1006/obhd.2000.2907

[26] Baker, R.J., Laury, S.K. and Williams, A.W. (2007) Comparing Small-Group and Individual Behavior in LotteryChoice Experiments. CAEPR Working Paper No. 2007-018. http://dx.doi.org/10.2139/ssrn.1015833.

[27] Masclet, D., Colombier, N., Denant-Boemant, L. and Lohéac, Y. (2009) Group and Individual Risk Preferences: A Lottery-Choice Experiment with Self-Employed and Salaried Workers. Journal of Economic Behavior and Organization, 70, 470-484. http://dx.doi.org/10.1016/j.jebo.2007.11.002

[28] Shupp, R.S. and Williams, A.W. (2008) Risk Preference Differentials of Small Groups and Individuals. The Economic Journal, 118, 258-283. http://dx.doi.org/10.1111/j.1468-0297.2007.02112.x

[29] Abdellaoui, M., L’Haridon, O. and Paraschiv, C. (2013) Individual VS. Couple Behavior: An Experimental Investigation of Risk Preferences. Theory and Decision, 75, 175-191. http://dx.doi.org/10.1007/s11238-012-9322-7

[30] He, H., Martinsson, P. and Sutter, M. (2012) Group Decision Making under Risk: An Experiment with Student Couples. Economics Letters, 117, 691-693. http://dx.doi.org/10.1016/j.econlet.2011.12.081

[31] Cooper, D. and Kagel, J. (2005) Are Two Heads Better Than One? Team versus Individual Play in Signaling Games. American Economic Review, 95, 477-509. http://dx.doi.org/10.2307/4132726 